descriptions by Lindley, Hooker, De Candolle, \&c. This Index we think is likely to prove useful to botanists at large, and especially to those who are interested in the history of cultivated plants, and who may wish to know where to lay their hands on figures or descriptions of them.

THE applications of science at least seem to be obtaining some attention at the Antipodes; Stillwell and Co., of Melbourne, send us the following announcement of a new work to be published by them: "The Chemistry of Agriculture," by R. W. Emerson MacIvor, A.I.C., F.C.S., \&c., lately Senior Demonstrator of Theoretical and Practical Chemistry, Anderson's University, Glasgow, with Appendices: Victorian Geology in its Relation to Agriculture, by Norman Taylor (of the late Geological Survey). The Conservation of Water for Agricultural and Pastoral Purposes, by G. Gordon, M.I.C.E. Suggestions on the Maintenance, Creation, and Enrichment of Forests, \&c., by Baron von Mueller, K.C.M.G., F.R.S., \&c.

THE Astro-physical Observatory on the Telegraphenberg, near Potsdam, was completed during September last, and has now been definitely handed over to its scientific directors.

Prof. Silvanus Thompson has published a pamphlet of $74 \mathrm{pp}$. on apprenticeship schools in France, a subject on which he read a paper at the recent meeting of the British Association. The little book deserves the attention of all interested in technical education.

THE West London Scientific Association issue a very satisfactory Report for $x 878-9$.

THE museum of the St. Petersburg Academy of Sciences has made a valuable acquisition in the head of a Rhinoceros tichorhinus, very well preserved and covered with patches of hair. It is a part of a nearly complete carcass which was discovered on the banks of a tributary of the Yana, some 130 miles north of Verkhoyanak,

MessRs. CAŚSELI have sent us the first two parts of a work on "European Ferns," illustrated by beantifully coloured plates. The text is by Mr. James Britten.

We notice a useful publication undertaken by the Kieff Society of Naturalists, being a complete index of all works on mathematics, natural science, and medicine that have appeared in Russia during the years 1872 to 1877 . The index for these five years has already appeared.

ANOTHER useful private undertaking is a weekly paper, Ressiyskaya Bibliografic (Russian and Slave Bibliography), appearing at St. Petersburg; it contains the titles of all Russian and Polish publications, with short notices about some of them.

MessR. GRIFFITH AND FARRAN will shortly publish a book entitled "On the Leads ; or, What the Planets Saw." The object of the work is to bring the planets of our system into nearer acquaintance, making each give an account of itself to a little girl who watches them through her father's telescope on the leads of the house; their mythological character being made the mouthpiece of their astronomical and physical history. It is written and illustrated by Mrs. A. A. Strange Butson.

THE additions to the Zoological Society's Gardens during the past week include two Bonnet Monkeys (Macacus radiatus) from India, presented respectively by Mr. S. E. Phillips and Mr. J. E. Medley; a Macaque Monkey (Macacus cynomolgus) from India, presented by Mrs. Franklin; a Lesser Black-backed Gull (Larus fuscus), British, presented by the Rev. F. H. Addams; a Mississippi Alligator (Alligator mississippiensis) from North America, presented by Capt. J. H. Mortimer; a Garnett's Galago (Galago garnetti) from East Africa, a Banded Ichneumon (Herpestes fasciatus) from West Africa, a Sœmmerring's Antelope (Gazella semmerringi) from Abyssinia, two Dufresne's Amazons (Chrysotis dufresniana) from South-East Brazil, purchased.

\section{THE SANITARY CONGRESS}

$T$ HIS Congress continued its meetings at Croydon during last week, when several interesting addresses were given. Mir. Douglas Galton, in his address last Thursday, spoke of that large class of conditions which are the direct result of the circum. stances to which man is exposed in consequence of living in communities. All living beings are in a continual condition of change, which results in their throwing off from the body matters which poison earth, air, and water, unless space, time, and opportunity are afforded for the counteraction of these deleterious effects. He showed how thus resulted both epidemic and zymotic diseases, the presence or absence of which in any locality, and the degree of their virulence depend on the sanitary surround ings. Cholera and dysentery are principally connected with the condition of the water supply; while an epidemic prevails the question whether a given population shall suffer or escape may almost be predicted from a chemical analysis of the drinking water. - It is to the physiologist and the chemist that we must look for the causes from which these baneful effects arise, and what are the conditions which should be altered to prevent or remove them. The engineer steps in after these causes have been pointed out, and it is for him to design the methods of prevention or removal.

In places where many dwellings are congregated together the requirements for health may be classed as-first, those that are common to the community, such as the supply of good water, the removal of foul water, and the removal of refuse matter; and secondly, those which immediately concern the individual house. holder, such as the condition of his house and the circumstances of its occupation. It is the interest of every person in a com. munity that every other member of the community should live under conditions favourable to health. Each year, as the population increases and as dwellings multiply, so does the importance of promoting these conditions increase; and so long as preventible diseases exist throughout the country, we must not delude ourselves with the idea that we have done more than touch the borders of sanitary improvement. There are few subjects in which so many professions of progress have been made in the last few years as in the theoretical knowledge of how to provide a healthy dwelling and a healthy town. Books innumerable have been written upon the question. Physiologists have invented every conceivable theory ; patentees have invented every conceivable description of apparatus; engineers, architects, and builders overwhelm you with professions of their knowledge of sanitary principles, and millions of money have been spent in furthering the schemes they have devised; and yet, in spite of all these efforts, there are few houses and very few towns where you would not easily detect some grievous sanitary blunders. Mr. Galton believes this to be due, in the first place, to the fact that the majority of men prefer anything to thinking for themselves. They like to obtain their knowledge as they do their hats-from a shop, ready-made. In the second place, the sanitary education of the country has not been brought into a system. In the third place, it has always seemed to Mr. Galton that the system under which the Government advances money for sanitary works, whilst of great prima facie advantage in one point of view, yet has its disadvantageous aspect. Mr. Galton then entered into some detail as to the best system to be adopted for encouraging and carrying out sanitary works.

He thinks that." we should have reached a higher level of sanitary improvement in this country than now prevails, if the Government had limited itself to its more legitimate functions, viz., first, the enactment of laws requiring sanitary defects to be removed; and second, the promotion of measures for diffusing $a_{\text {. }}$ sound education in sanitary knowledge ; instead of pursuing the course of endeavouring to dictate the exact measures to be followed in each case. But it may be asked, What is sanitary knowledge? It is frequently assumed that drainage and watersupply are the principal subjects which are embraced in the term; but these only make up a small part of the subject. At the present time there does not exist any treatise which brings to a focus the various problems of mechanical and physical science, upon which the knowledge is based.

$\mathrm{Mr}$. Galton then gives several instances in connection with the construction of houses to illustrate the variety of the problems to be solved. A sanitarian tells us that health depends on pure air and pure water. If a site is to be selected, it requires a consideration of its position with respect to its surroundings. It requires a knowledge of the temperature of the air and of the soil ; what are the 
prevailing winds; what is the amount and incidence of the rainfall; and what is the percolative capacity of the soil. The engineer cannot interfere with the general conditions of a climate, but he may produce important changes in the immediate surroundings of a locality : he may modify the condition and temperature of the soil; he may control atmospheric damp; he may arrange for the rapid removal of rainfall, or he may cause the rainfall to be retained in the soil, to be given out grachually in springs, instead of passing away in torrents to flood the neighbouring districts.

Mr. Galton showed by comparing the death-rate in the model lodging-houses in London with that of other districts that any extraordinary degree of unhealthiness in towns is unnecessary.

One important step in knowledge of sanitary construction is to learn how to obtain pure air in a building. What is pure air? What are the impurities which malse the air of a town so different from the fresh air of the country? The volume of sulphuric acid from coal thrown up by our fires into London air is enormous. A cubic yard of London air has been found to contain nineteen grains of sulphtrous acid. The street dust and mud is full of ammonia from horse-dung. The gases from the sewers pour into the town air. Our civilisation compels us to live in houses, and to maintain a temperature different from that out of doors. What are the conditions as to change under which we exist out of doors? Mr. Galton then proceeded to show that it is all but impossible to maintain a supply of pure air indoors. Any ventilating arrangements are only makeshifts to assist in remedying the evils to which we are exposed from the necessity of obtaining an atmosphere in our houses different in temperature from that of the outer air. On the other hand, means might be adopted to obtain as pure air as we can. Suspended matters exist in much smaller quantities at an altitude; at 100 feet they are greatly diminished; at 300 feet the air is comparatively pure. In Paris the air for the Legislative Assembly is drawn down from a height of I 80 feet, so as to be taken from a point above many of the impurities of the town atmosphere. That is a reasonable and sensible arrangeinent, and might be usefully adopted in public buildings in towns. In the Houses of Parliament the so-called fresh air is taken from courtyards on the street level, from which horse traffic is not excluded. The maintenance of the standard of purity, or rather impurity, in a building, depends on ventilating arrangements. Ventilation chiefly depends on the laws which govern the movement of air, its dilatation by heat or contraction by cold; or, if ventilation is effected by pumps and fans, then upon the laws of the motion of air in channels, the friction they entail, and sinilar questions; therefore all these are matters for careful study. But when we apply the study to practice, other considerations occur. It may be summed up that, whatever the cubic space, the air in a confined space occupied by living beings may be assumed to attain a permanent degree of purity, or rather impurity, theoretically dependent upon the rate at which emanations are given out by the breathing and other exhalations of the occupants, and upon the rate at which fresh air is admitted, and that, therefore, the same supply of air will equally well ventilate any space, but the larger the cubic space the longer it will be before the air in it attains its permanent condition of impurity. Moreover, the larger the cubic space, the more easily will the supply of fresh air be brought in without altering the temperature, and without causing injurious draughts. "A room warmed by an open fire," Mr. Galton maintains, "is pleasanter than a room warmed by hot-water pipes. A warm body radiates heat to a colder body near to. it. The heat rays from a flame or from incandescent matter pass throngh the air without heating it; they warm the solid bodies upon which they impinge, and these warm the air. Where the source of heat in a room consists of hot-water pipes, or low-pressure steam pipes, the air is first warmed, and imparts its heat to the walls. The air is thus warmer than the walls. When a room is warmed by an open fire, on the other hand, the warming is effected by the radiant heat from the fire, which passes through the air without sensibly warming it; the radiant heat warms the walls and furni. ture, and these impart their heat to the air. Therefore the walls in this case are warmer than the air. Consequently, in two rooms, one warmed by an open fire, and the other by hot-water pipes, and with air at the same temperature in both rooms, the walls in the room heated by hot-water pipes would be some degrees colder than the air in the room, and therefore colder than the walls of a room heated by an open fire; and these colder walls would therefore abstract heat from the occupants by radiation more rapidly than would be the case in the room heated by an open fire. And to bring the walls in the room heated with bot- water pipes to the came temperature as the walls in the rooms heated by the open fire would require the air of the room tooms heated to an amount beyond that necessary for comfort, and therefore to a greater amount than is desirable. Besides theoretical knowledge, it is of essential importance that the sanitary architect, builder, or engineer, should have also practical technica! knowledge of the subject. He should know what constitutes a good material and good workmanship. It is not only the officers of the army of sanitary constructors who require knowledge and education, but the foremen and the labourers, each in his own degree."

Prof. Corfield's address was on Sanitary Fallacies. After an interesting historical részmné, he dealt with some fallacies of the present day. Against all sanitary improvements whatever we find one argument continually brought-that things have gone on in the same way for many years, and there is no reason why they should. be changed, that our forefathers from generation to generation lived under unsanitary conditions, and why should we not do the same? that cholera, or enteric fever, or diphtheria has never broken out in a place, or in a particular house, and so it need not be expected! Dr. Corfield showed how fallacious and mischievous this argument is. The arguments brought forward to support the spontaneous origination of the poisons of typhus and enteric feve:s, of diphtheria, and of cholera, are most of them fallacious in the extreme, and the argu. ments advanced to prove the de novo origination of the poison of enteric fever, are of themselves sufficient to render it in the highest degree improbable. They are, indeed, so weak, that no one really capable of judging the value of a scientific argument, could from them come to any other conclusion than that the position was untenable. But a practical and very serious mischief has arisen from the spread of these doctrines. In the majority of zases no pains are taken to destroy the excremental discharges of patients suffering from such diseases, a neglect apt to lead to very dangerous consequences.

"But," Dr. Corfield went on to say, "there is still a great fallacy abroad in connection with the question of the removal of refuse matters from the vicinity of habitations. People talk and write as if the watermcarriage system and the Conservancy systems stood upon the same footing-the principal of the one being the immediate removal of excretal matters from houses, and that of all the others being, as their name indicates, the keeping of such matters in and about the house for a certain time. The one is a correct principle, the other is a false one, and it is no argument at all to say that where the water-carriage system is badly carried out, the result may be worse than where the Conservancy system is carefully managed. In sanitary matters, as well as in everything else, we should follow correct principles. If we do not, but by arguments equally specious and fallacious, try to persuade ourselves that 'practically speaking' (according to the cant phraseology of the day) better results may be obtained by following false principles, nothing is more certain than that by an inexorable law of nature true principles will assert their position, and we shall be punished for our mistake by being landed in difficulties greater than we had to contend with at the outset. It is a very old and often-exposed fallacy to argue against the use of a thing from the abuse of it, and to argue against the water-carriage system because when surface drains have been called upon to do the duty of sewers, for which they were not intended, and of which they are not capable, or because the sewage has been turned into the water-courses, which have thus become unfit to supply water for domestic purposes, is an excellent example of this kind of fallacy."

Dr. Corfield went on to show that water containing the least quantity of organic matter must be regarded as dangerous, and that absolutely pure water should be insisted on, as the only safe form for sanitary purposes. With regard to diet tics, Dr. Corfield referred to the fallacies which existed for some lime, as to the dietetic value of gelatine. He could not but thi $i k$ that it was a mistake to utterly condemn alcoholic liquors.

"There are those-" he said, " and I think there always will be-who cannot believe that the exquisite bouguet of the wines of France, of Italy, and of Spain is only fit to be smelt, there may even be those who are wicked enough to insinuate that if people do not taste them they show a lamentable deficiency in the cultivation of an important sense. He referred in conclusion to the anti-vaccination fallacy, and showed that statistics are dead against it.

Under the title of "Geology in Relation to Sanitary Science," $\mathrm{Mr}$. Alfred Haviland gave some valuable hints as to what would be the practical difficulty in realising any of the dreams of a 
future proper state of society. He showed that even under the most favourable conditions of physique and surroundings population would so increase that migration would be an àbsolute necessity, the emigrants thus finding themselves in conditions totally different from those they left. They would stand face to face with the stern reality of change; a change so great they could not realize it. Help is called for; and science like a good genius, extends her hand. The dreamer and the dream are gone. Large as our world may be, it never has been, and we have no grounds for believing it ever will be, a universal paradise: and without it becomes so, the people of the dream can never become realities, We find not a single writing in the stones that records evidence of either uniform climate, uniform soil, or uniform conditions of any kind whatever conducing to the perfection of existence either among the lower or the higher classes of animals. The very factor so necessary to the perfection of type, viz., health, is the great factor of productiveness; and this productiveness is the factor of destruction by overcrowding. Over and over again has this been recorded on the rocks.

Man has not only spoiled many of the sites which his ancestors wisely selected as vantage gromds against the foe, the flood, and the drought; but is hourly spoiling his own form by his artificial habits, and laying at the same time the foundation for a still further departure from a natural standard in his offspring. He is polluting the soil on which his habitations stand, he is befouling his water-courses and springs, and he is poisoning the air he breathes. He has thus created surroundings from which he can with difficulty escape. "Now I hold," Mr. Haviland said, "that any institute establishec for the purpose of teaching us the science of living in a cleanly and wholesome mamer -as regards water, air, and soil-should first of all teach in its schools what has already been tanght by such men as I have mentioned, as a wholesome restraint against the pricle which a little knowledge engenders. Before we can boast of any sanitary science, let us be able to point to our researches on the climates, the soils, the diseases we find at home and abroaf in our vast colonies. Let the crust of the earth in various parts of the globe be thoroughly examined in its relation to diseases-recollecting that had not man been born, there are certain spots in this earth that produce certain specific poisons, the chemical constitution of which we know nothing. Such spots sizould be mapped, after having been thoroughly investigated as to soil and climate, for the use of emigrants, colonists, and those in command of our expensive but necessary soldiery."

\section{UNIVERSITY AND EDUCATIONAL} INTELLIGENCE

Canididag.-During Prof. Maxwell's illness, Mr. W. Gamett is lecturing for him at the Cavendish Laboratory, on Voltaic Electricity, Electro-magnetism, and Electric Measurements; the lectures are experimental. Mr. Gamett is also giving a more elementary experimental course of lectures on Mechanics and Hydrostatics, adapted to candidates for the First M.B. and First Part of the Natural Sciences Tripos. Prof. Stuart's work shop will be open for pupils this term at the New Museums. Practical instruction in the use of tools in wood or metal is provided, and further practical instruction for those who alreaciy have a sufficient knowledge of the use of the tools. During the present term his lectures will be on Mechanism. Mr. W. J. Lewis, M.A., Fellow of Oriel College, Oxford, has been incorporated as M.A. of Cambridge, and entered at Trinity Collese. Prof. W. H. Miller, F.R.S., Professor of Mineralogy, being in ill-health, $M r . W . J$. Lewis has been appointed his deprity for twelve months, and Prof. Miller has assigned twothirds of his whole anmal stipend to his deputy. Mr. Lewis has for some time been working very assiduously in the Mineralogical Musenm, and is now lecturing on Mineralogy, while in the Easter Terw he intends to lecture on Crystallography and Crystallographic Physics. Next term Prof. Stuart's lectures will be on the Theory of Structures. Prof. Challis's lectures on Practical Astronomy are postponed on account of ill-health. Prof. Cayley will lecture this term on Differential Equations.

THE City and Guilds of London Institute for the Advance. nent of Technical Education, announce the opening of their echnical classes, at Cowper Street School, Finsbury. In the jection of applied physics, Mr. W. E. Ayrton will deliver a sonise of twelve lectures on "Some of the Practical Applicaions of Electricity and Magnetism," commencing on Monday, Novemuer 3, at 7 p.in. In that of applied chemistry, Dr. H. Armstiong; F. R, S., will deliver' a similar course on "The First
Principles of Chemistry," commencing Wednesday, November 5 , at $8 \mathrm{p} . \mathrm{m}$. An inaugural lecture $\mathrm{w} 11$ be delivered by $\mathrm{Mr}$. Ayrton, on Saturday, November 1 , at $8 \mathrm{p}, \mathrm{m}$, on "The Improvement Science can Effect in our Trades, and in the Con. dition of our Workmen." A class in connection with this for the study of blowpipe analysis and assaying, will be commenced next week at the Birkbeck Institution, by Mr. G. Chaloner, F.C.S.

\section{SOCIETIES AND ACADEMIES}

Academy of Sciences, October 20.-M. Daubrée in the chair.-The following papers were read:-Researches showing the power, the rapiclity of action, and the varieties of certain inhibitory influences of the brain on itself or on the spinal cord, and of this latter centre on itself or on the brain, by $M$. BrownSéquard.-Discovery of a suall planet, by Mr. Peters (telegram from the Smithsonian Institution). - Observation of the tplanet 206, Peters, at the Paris Observatory, by MM. Henry.Observations of declination, inclination, and horizontal intensity in the basin of the Mediterranean, by M. de Bernardiére. These observations were made during a voyage of the training-ship, La Flore, in 1878.79 . The numbers for some twenty-six places are tabulated.--On whole functions, by M. Picard.--On the Laurent saccharimeter, by M. Laurent. Two improved models were presented, giving more light and distinctness, while the reflections in the tubes are suppressed,-New researches on the mode of union of cells of the mucous bodies of Malpighi, by M. Ranvier. These cells, formed of masses of protoplasm with nuclei, are tinited by protoplasmic filaments, which are common to them and each of which does not result from junction of two filaments placed end to end, nor is the nodule occupying their raiddle the mark of a junction or juxtaposition; it is an elastic organ, which allows of easy enlargement of the spaces destined for circulation of nutritive juices between the cells. - On asphyxic glycrmia, by M. Dastre. Cl. Bernard affirmed that a prolonged asphyxic state destroyed the glycogen of the liver, and made the sugar disappear from the blood. Some physiologists hold, on the contrary, that in accordance with Lavoisier's theory, sugar accumulates in the blood when the oxygen (for its combustion) is diminished. M, Dastre considers we must clistinguish between the effects of rapid asphyxia, immediately consequent on with. drawal of oxygen, and the consecutive effects of slow asphyxia (such as wasting of tissues and exhaustion of reserves). Rapid asphyxia way be realised in two ways, making an animal breathe air confined in a closed vessel, or maling it breathe in rarefied air constantly renewed. Fle tried both on dogs, and found the quantity of sugar in the blood to vary in contrary direction to the quantity of oxygen (less oxygen, more sugar).

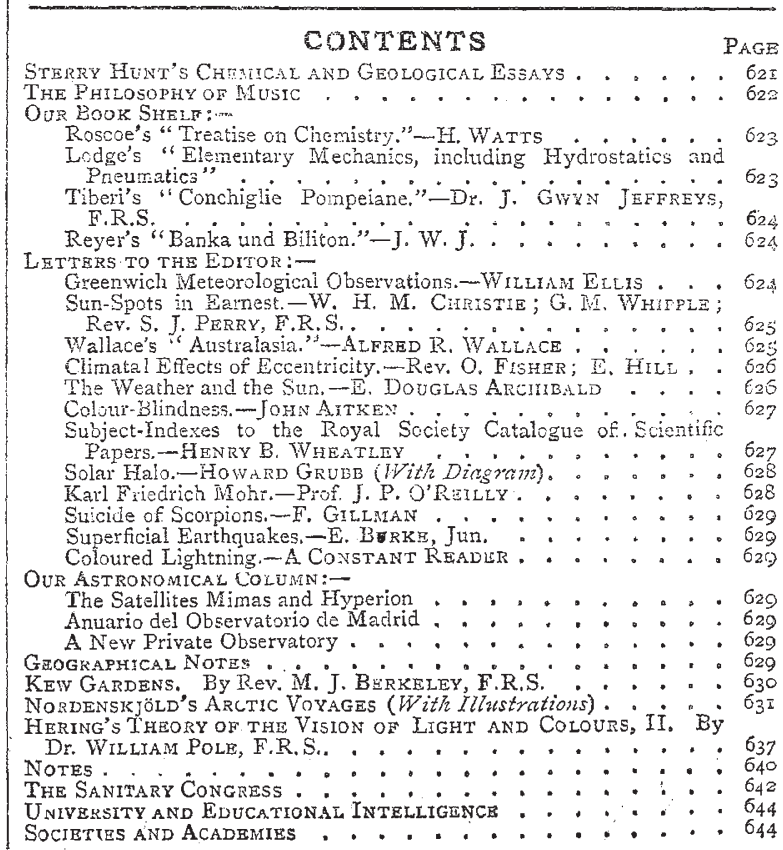

